\title{
Cost Implications and Profitability of the Artisanal Fish Smoking Enterprise
}

\author{
Nwazuo Ngozi Ihechiluru ${ }^{1}$, Keke Ibeawuchi Romanus ${ }^{2}$, Egbo Ikechukwu $^{3}$, \\ Egeruoh Amarachi Stella ${ }^{1}$ \\ ${ }^{1}$ Department of Biology, School of Sciences, Alvan Ikoku Federal College of Education, Owerri, Imo State, Nigeria \\ ${ }^{2}$ Department of Fisheries and Hydrobiology Research Unit, School of Biological Sciences, Imo State University, Owerri, Nigeria \\ ${ }^{3}$ Department of Mathematics, School of Sciences, Alvan Ikoku Federal College of Education, Owerri, Imo State, Nigeria
}

\section{Email address:}

ninaensquaredudu@gmail.com (N. N. Ihechiluru)

\section{To cite this article:}

Nwazuo Ngozi Ihechiluru, Keke Ibeawuchi Romanus, Egbo Ikechukwu, Egeruoh Amarachi Stella. Cost Implications and Profitability of the Artisanal Fish Smoking Enterprise. Computational Biology and Bioinformatics. Vol. 4, No. 3, 2016, pp. 21-26.

doi: $10.11648 /$ j.cbb.20160403.11

Received: May 10, 2016; Accepted: May 25, 2016; Published: July 13, 2016

\begin{abstract}
Descriptive statistics, content analysis and cost, return and profit functions where used to analyze the profitability of the artisanal fish smoking enterprise using fish directly captured from Oguta lake, Nigeria. Fresh fish was purchased from both fishermen and retailers and smoking was done in a completely local way to mimic the exact experience of the fish generally sold in the market. Results revealed that the most revenue is obtained when fresh fish purchased from wholesaler/ fishermen, are smoke dried and sold at urban market as it is estimated that $46.54 \%$ profit is made from fish purchased from wholesalers, processed and sold in the rural market and $88.22 \%$ profit made from fish purchased from wholesalers, processed and sold in the urban market while $5.01 \%$ and $26.45 \%$ profit is made from the sale of fish purchased from retailers, processed and sold in the rural and urban markets respectively. In general, there is profit in the fish smoking enterprise thus, a very good business to embark upon.
\end{abstract}

Keywords: Cost, Profit, Artisanal, Fish Smoking

\section{Introduction}

Fish is generally accepted as protein source in diets of average Nigerians [1]. Fish is more acceptable than other forms of animal protein as there are no social, cultural or religious taboos associated with its consumption. In fact, [2] reports that several factors are responsible for this level of importance which include; its relatively low price; its nutritional superiority over other meats; its relative storability when processed into dry and smoked products; its ability to enhance mental health (IQ) in developing children and its ability to mitigate various arteriosclerosis conditions in adult population. Fish represents about 55\% of the protein sources intake of Nigerians [3]. Historically, artisanal fishery in Africa, dominated by fishermen in canoes and boats has provided fish as a nutritious source of food and has contributed to the $80 \%$ of fishes produced locally in Nigeria [4].
Owing to the fact that fish is susceptible to deterioration without any preservative or processing measure [5], proper processing techniques are employed to prolong its shelf life so that it does not lose quality, taste, odor and nutritional value. A number of processing techniques, such as, smoking, chilling, salting, drying and fermentation are employed by fish processors in Nigeria. However, smoking is the affordable and most widely used method for fish preservation in Nigeria, Ghana and other West African countries [6]; [7]. Smoking is the process of flavoring, cooking or preserving food by exposing it to smoke from burning or smoldering material; most often wood. Different techniques of smoking fish exists and vary from country to another, based on tradition, preferred tastes and market preferences. The use of this cheaper preservation process is affected by lack or inconsistent electricity supply [8] and freezing/chilling technology which are too expensive for rural communities. In smoking method, all the preparatory processing operations of 
washing, cutting, degutting, de-scaling, sorting, salting are preformed manually [8]. The desirable effects of smoking on foods are flavoring, preservation and coloring however, undesirable effects of contamination with toxic components of smoke the PAH such as benzo (a)-pyrene and destruction of some essential amino acids is not entirely ruled out. Salted smoked fish has been demonstrated to be much preferable to non-salted smoked fish but because of the extra cost associated with salting, it has not been accepted as a tradition in fish smoking. [9] noted that fish processed will more likely fetch a lower price than if it had been sold in fresh form, approximating price fall of $30 \%$ as consumers generally prefer fresh fish as opposed to cured fish. In Nigeria, the production system is mainly artisanal and fish are marketed mostly in five different forms; fresh, smoked, dried, salted and frozen [10] all of which vary in their capital requirements, technological complexities, raw material requirement, nutritional and organoleptic quality of the processed products. In spite of the rudimentary technique of the traditional methods employed by artisanal fishermen and processors, this sub-sector still produces most of the fish products readily available for consumers. This research experimented to find out the cost implications and profitability of employing artisanal fish smoking method as is commonly employed in Nigeria as such information will bring to limelight opportunities resident in fisheries and help consumers justify their spending on fish.

\section{Materials and Methods}

\subsection{Collection of Fish Samples}

Twelve live Heterobranchus spp harvested by the use of hook and line of both sex with average length of 28.5 inches and average weight of $4 \mathrm{~kg}$ were purchased from the waterside wholesalers and retailers at Afiafor landing site in Oguta fishing community, Imo state- six fish each from wholesalers and retailers and kept in separate plastic basins. Before its purchase, fish samples were carefully selected to reduce to a minimum mechanical damage on sample fish and to ensure that fish is rendered free from any other blemishes. Length and weight of fish were measured and values recorded. Choice of wholesaler and retailer from which sample fish was purchased from was based on the person that gave the least price for the best size of fish after oral bargaining was done. Fish purchased from the waterside wholesaler and that purchased from retailer were then carried to a waterside processor who was paid to smoke the fish just as she would for usual commercial production except that the both fish sample would receive the same treatment but be handled separately. During processing, the processor was carefully observed to ensure that any forms of error in the quantity of fish given to be processed and the quantity finally taken to the market are completely removed.

\subsection{Preparation of Sample Fish}

Fish was placed on a worktable and hit hard with a cutlass on the head to stuns the fish, rendering it motionless so it could be cut into sizeable pieces. The guts and gills were removed to reduce moisture in fish and messy parts in the final product. Cut fish were carefully washed in a basin of water to remove blood, sand and excess slime from the flesh. It was then transferred into another basin containing salt solution for brining- a solution made of $250 \mathrm{~g}$ of table salt in 20 litres of water for each treatment and left to stand for twenty minutes so the fish flesh properly absorbed the salt. Fish samples are then removed from the brine unto a tray for excess water to drip off fish after which the fish was ready for the kiln.

\subsection{Smoking Process}

Fish smoking was done on a metal drum kiln created with a mesh tray atop it, under which a fire place is provided, into which big logs of fire wood are inserted and lighted. The fish are arranged on the mesh tray and covered with a zinc sheet which functions to conserve heat, allow convection from the zinc sheet unto the fish and prevent dust from reaching fish as it smokes. The fishes are smoke-dried, starting with a smoldering fire at about $60-80^{\circ} \mathrm{C}$ for 120 minutes to enable the smoke to be absorbed by the fluid on the fish as gradual smoking progresses. The smoking continued at a relatively higher temperature, using less smoke during the second phase as the fire is carefully controlled to maintain a range of 80 $100^{\circ} \mathrm{C}$ for about four hours in order to cook the fish but avoid burning. Fish are placed with the cut portions facing upwards and downward with the exception of the head and tail which are placed, with the dorsal region facing the upwards so that it can cook with the fluid in it. It is later turned over for drying process to begin as it begins to exude oil. To ensure that the products are evenly cured, the fish are inspected, turned, and rearranged on the tray every two to three hours. Smoking continues at a much-reduced heat for extra hours. Regulation of heat is done by adding or removing firewood accordingly with the entire smoking process lasting for 26 hours. After it has dried to about $10 \%$ moisture remnant in it, smoked products are removed by hand picking from the kiln unto a metal tray where it stays to cool. Each set of sample were weighed, divided into two parts and packaged in airtight plastic bags ready for the market.

\subsection{Sale of Fish and Profit Estimations}

Smoke dried fish in which the fresh form was purchased from the wholesaler was randomly divided into two parts; one part of the fish was sold in urban market while the other parts sold in the rural market. This was replicated for the fish purchased from the retailer. Fish sold in the urban market were given to a trader in Ekeonua market, Owerri to sell while that sold in the rural market was sold at Afiafor market, Oguta. Transportation cost and commission for selling was given to the urban trader when she had brought the return. Quantity of fish bought from wholesalers $\left(\mathrm{X}_{\mathrm{w}}\right)$ and retailers $\left(\mathrm{X}_{\mathrm{r}}\right)$; the prices corresponding to such fish $\left(\mathrm{K}_{\mathrm{w}}\right.$ and $\left.\mathrm{K}_{\mathrm{r}}\right)$; prices for which the fish bought from different sources are sold at urban and rural markets $\left(\mathrm{p}_{1}\right.$ and $\left.\mathrm{p}_{2}\right)$; the transportation 
cost $(\mathrm{t})$; cost of extra additions during processing $\left(\mathrm{K}_{\mathrm{a}}\right)$; total commission paid to selling agents (c); maintenance cost of kiln and other equipment (mc); and finally depreciation value estimated from fixed cost of processing (dc) were all recorded and used for estimation of profit.

\section{Analysis of Data}

The analytical tools used include descriptive statistics (mean, percentage, frequency tables and cross tabulations), content analysis and cost, return and profit functions, as described [11].

Model Specification of Costs, Returns and Profits from Different Fish Processing Methods

i. Cost components of smoke drying Method

$$
\begin{aligned}
& \mathrm{Cs}_{\mathrm{w}}=\mathrm{X}_{\mathrm{w}} \mathrm{K}_{\mathrm{w}}+\mathrm{X}_{\mathrm{fw}} \mathrm{K}_{\mathrm{fw}}+\mathrm{X}_{\mathrm{a}} \mathrm{K}_{\mathrm{a}}+\mathrm{dc}+\mathrm{mc} \\
& \mathrm{Cs}_{\mathrm{r}}=\mathrm{X}_{\mathrm{r}} \mathrm{K}_{\mathrm{r}}+\mathrm{X}_{\mathrm{fw}} \mathrm{K}_{\mathrm{fw}}+\mathrm{X}_{\mathrm{a}} \mathrm{K}_{\mathrm{a}}+\mathrm{dc}+\mathrm{mc}
\end{aligned}
$$

Where:

$\mathrm{Cs}_{\mathrm{w}}=$ Total cost of fish processing with kiln (in which fresh fish was purchased from wholesaler)

$\mathrm{Cs}_{\mathrm{r}}=$ Total cost of fish processing with kiln (in which fresh fish was purchased from retailer)

$\mathrm{X}_{\mathrm{w}}=$ Average quantity of fresh fish purchased from wholesaler

$\mathrm{X}_{\mathrm{r}}=$ Average quantity of fresh fish purchased from retailer

$\mathrm{K}_{\mathrm{w}}=$ Average price (A) corresponding to $\mathrm{X}_{\mathrm{w}}$

$\mathrm{K}_{\mathrm{r}}=$ Average price (N) corresponding to $\mathrm{X}_{\mathrm{r}}$

$\mathrm{X}_{\mathrm{fw}}=$ Quantity (in bundles) of fire wood used for fish processing

$\mathrm{K}_{\mathrm{fw}}=$ Unit price ( $)$ corresponding to $\mathrm{X}_{\mathrm{fw}}$

$\mathrm{X}_{\mathrm{a}}=$ Quantity of extra flavoring additives used for fish processing

$\mathrm{K}_{\mathrm{a}}=$ Unit price ( corresponding to $\mathrm{X}_{\mathrm{a}}$

$\mathrm{dc}=$ Depreciation value estimated from the fixed costs of fish processing using kiln (

$\mathrm{mc}=$ total maintenance cost of kiln and other equipment $(\mathrm{N})$

ii. Return components of smoke drying method

Sales of smoked dried fish obtained by processing different quantities of fresh fish purchased from wholesaler and retailer generate the returns $R_{w}$ and $R_{r}$ respectively. However, place of sale (rural or urban market) will have influence on the magnitude of the returns $\left(R_{w}\right.$ and $\left.R_{r}\right)$ due to spatial price variation.

These returns will be estimated using the following mathematical relations:

$$
\begin{aligned}
& \mathrm{R}_{\mathrm{wr}}=\mathrm{q}_{1} \mathrm{p}_{1} \\
& \mathrm{R}_{\mathrm{rr}}=\mathrm{q}_{2} \mathrm{p}_{1} \\
& \mathrm{R}_{\mathrm{wur}}=\mathrm{q}_{1} \mathrm{p}_{2} \\
& \mathrm{R}_{\mathrm{rur}}=\mathrm{q}_{2} \mathrm{p}_{2}
\end{aligned}
$$

Where:

$\mathrm{R}_{\mathrm{wr}}=$ returns (N) from sales of smoked fish at rural market; in which the fresh form was purchased from wholesaler;

$\mathrm{R}_{\mathrm{wur}}=$ returns ( $\mathrm{N}$ ) from sales of smoked fish at urban market; in which the fresh form was purchased from wholesaler;

$\mathrm{R}_{\mathrm{rr}}=$ returns (N) from sales of smoked fish at rural market; in which the fresh form was purchased from retailer;

$\mathrm{R}_{\text {rur }}=$ returns (N) from sales of smoked fish at urban market; in which the fresh form was purchased from retailer.

$\mathrm{q}_{1}=$ Quantity of smoked dried fish sold that is corresponding to $\mathrm{X}_{\mathrm{w}}$.

$\mathrm{q}_{2}=$ Quantity of smoked dried fish sold that is corresponding to $\mathrm{X}_{\mathrm{r}}$.

$\mathrm{p}_{1}=$ Unit price of the smoked dried fish at rural market.

$\mathrm{p}_{2}=$ Unit price of the smoked dried fish at urban market.

iii. Profit components of smoke drying method

$$
\begin{aligned}
& \text { Gswr }=R_{w r}-C_{w} \\
& \text { Gswur }=R_{w u r}-C_{w}-t-c \\
& \text { Gsrr }=R_{r r}-C_{r} \\
& \text { Gsrur }=R_{r u r}-C_{r}-t-c
\end{aligned}
$$

Where:

Gswr = Profit from smoke drying of fish using kiln; in which the fresh fish was purchased from wholesaler and smoked form of the fish was sold at rural market.

Gswur = Profit from smoke drying of fish using kiln; in which thefresh fish was purchased from wholesaler and smoked form of the fish was sold at urban market.

Gsrr $=$ Profit from smoke drying of fish using kiln; in which the fresh fish was purchased from retailer and smoked form of the fish was sold at rural market.

Gsrur $=$ Profit from smoke drying of fish using small kiln; in which the fresh fish was purchased from retailer and smoked form of the fish was sold at urban market.

$\mathrm{t}=$ transportation cost

$\mathrm{c}=$ total commission paid to selling agents

It should be noted that transportation cost and commission paid to selling agents appear as additional cost applicable only in the urban market and not applicable in the rural market scenario.

\section{Results and Discussion}

\subsection{Capital Investment in Artisanal Smoke Drying in the Study Area}

In the study area, fixed inputs includes metal drum smoking kiln, wire mesh, zinc sheet, metal tray, plastic basins, work table and knives of which the sizes, durability and life expectancy of the different equipment varies. The annual maintenance of smoking equipment, investment cost and daily depreciation of processing equipment were estimated and categorized according to number of equipment used (table 1). Daily depreciation and maintenance cost was used for the estimation because the experiment lasted for 26 hours (a day and two hours). 
Table 1. Fixed inputs, cost and daily depreciation value in artisanal fish processing.

\begin{tabular}{llllll}
\hline Fixed input & No & Purchase value (\#) & Expected life in days & *Daily depreciation (\#) & Maintenance cost per day (\#) \\
\hline Metal drum & 1 & $4,500.00$ & 730 & 6.16 & - \\
Wire mesh & 2 & 100.00 & 1095 & 0.18 & - \\
Metal tray & 1 & 500.00 & 1460 & 0.34 & - \\
Plastic basin & 1 & 250.00 & 1095 & 0.23 & - \\
Work table & 1 & $1,500.00$ & 2190 & 0.68 & 6.54 \\
Zinc sheet & 2 & 250.00 & 365 & 1.37 & - \\
Knife & 1 & 500.00 & 1460 & 0.34 & 0.82 \\
Total & & 7600.00 & & 9.30 & 7.36 \\
\hline
\end{tabular}

Source; Field survey, 2015

*Straight line depreciation method is used.

\subsection{Operational Cost of Smoke Drying Fish in the Study Area}

For the operation of fish smoking, several variables were used which are not fixed. These variable inputs include fresh fish, firewood, salt, and water of which varied greatly depending on quantity of fish processed and demand of consumer. Information on these inputs is provided in table 2 and these values are used for the estimation.

Of note is that water is freely made available at landing sites from the lake, as such, cost of water is not inputted into the cost calculations of variable inputs. Transportation of fish to the urban market is estimated at an average of $\$ 340$ while commission paid to selling agents is 100 .

Table 2. Quantity and cost of variable inputs in smoke drying process.

\begin{tabular}{llll}
\hline Variable input & *Average quantity & Average price per input (\$) & Average total cost (₹) \\
\hline **Fresh fish & 12 & 2500 & 30,000 \\
Fire wood & 4 & 100 & 400 \\
Salt & 2 & 50 & 100 \\
Water & 2 & - & - \\
Total & & & 7250 \\
Transportation & & & 340 \\
Commission & & 100 \\
\hline
\end{tabular}

*unit of measurement

Fresh fish- per one (4kg weight and 28.5 inches long)

Fire wood- in bundle

Salt- $250 \mathrm{~g}$

Water- 20 litres

**Fresh fish- Heterobranchus spp

\subsection{Returns in Smoke Drying Enterprise}

The returns from fish smoking are the market value of the output (smoke dried fish) from processing. The market value varies depending on whether the processor sells at rural or urban market, where he/she buys the fresh fish from (fishermen or waterside traders) or the species of fish. Information required for estimation of revenue and returns are presented in table 3 . The quantity of smoke dried fish is a function of the quantity of fresh fish processed. From the investigation, every one small basin of fish that is processed generates an average of one and a quarter basin of smoked dried fish. This was found to be true due to stiffness of fish flesh after smoking causing spaces to be created between individual fish that would have otherwise completely overlapped on each other. Total weight of fresh fish is usually much more than when its smoked because of water content present in the fresh state.

From the experiment, processors tend to have a higher purchasing power when fresh fish are obtained from fishermen, thus increasing returns when compared to cost.

Table 3. Quantities processed and market prices of smoke dried fish.

\begin{tabular}{llllllllll}
\hline \multirow{2}{*}{$\begin{array}{l}\text { Place of } \\
\text { purchase }\end{array}$} & \multicolumn{2}{l}{ Purchase value (\$) } & \multicolumn{3}{c}{ Sale at Rural market (\$) } & \multicolumn{3}{c}{ Sale at Urban market (\$) } \\
\cline { 2 - 10 } & Qt & Value per fish & Total Price & Qt & Value per fish & Total Price & Qt & Value per fish & Total price \\
\hline Wholesaler & 6 & 2000 & 12000 & 3 & 3000 & 9000 & 3 & 4000 & 12000 \\
Retailer & 6 & 3000 & 18000 & 3 & 3200 & 9600 & 3 & 4000 & 12000 \\
\hline
\end{tabular}

Source: Result of investigation (2015) 
The local selling price of processed fish must be greater than fish processing costs [12]. Results of profits made from sale of smoke dried fish shows that the most revenue is obtained when fresh fish purchased from wholesaler/ fishermen are smoke dried and sold at urban markets. This is true because cost of buying is less, price of processed fish is higher at urban markets and quantity sold more. From results of the experiment, sale of smoke dried fish when their fresh forms are obtained from wholesaler and retailer generates returns or $R_{w}$ and $R_{r}$ respectively. The returns from sale of these fish in urban or rural market is given as $\mathrm{R}_{\mathrm{wur}}, \mathrm{R}_{\mathrm{wr}}, \mathrm{R}_{\mathrm{rur}}$ and $\mathrm{R}_{\mathrm{rr}}$.

\subsection{Profitability of the Smoke Drying Enterprise}

The mathematical relations defined in chapter three were used to determine the profitability of the enterprise. It was assessed by estimating the difference between total revenue obtained from the sale of the smoked product and the cost component involved in the processing and marketing. The estimation shown in appendix I shows a step by step procedure used in arriving at the profitability figures for the processing method in the study area. The scenario includes variation in cost components arising from the purchase of fresh fish from wholesalers or retailers and variations in revenue from sale of processed fish at rural or urban markets. Depreciation value and maintenance cost remained unchanged.

Table 4. Profit percentage obtained from the sale of fish.

\begin{tabular}{lllll}
\hline \multirow{2}{*}{ Place of purchase } & \multicolumn{2}{l}{ Rural market } & \multicolumn{2}{l}{ Urban market } \\
\cline { 2 - 5 } & *Profit (\#) & \% value & *Profit (\#) & \% value \\
\hline Wholesaler & 2858.34 & 46.54 & 5418.34 & 88.22 \\
Retailer & 458.34 & 5.01 & 2418.34 & 26.45 \\
\hline
\end{tabular}

*profit in relation to initial input cost

"Profitability" is a general term which measures the income that can be earned in a particular situation. From results of the calculations (table 4), it is estimated that $46.54 \%$ profit is made from fish purchased from wholesalers, processed and sold in the rural market and $88.22 \%$ profit made from fish purchased from wholesalers, processed and sold in the urban market. 5.01\% and $26.45 \%$ profit is made from the sale of fish purchased from retailers, processed and sold in the rural and urban markets respectively. In Africa alone, studies highlighted that the bulk of fisheries employment is in the post-harvest economic activities which includes fish processing and marketing [13] which proves why profits of this magnitude is recorded. Moreover, the added cost of marketing (advertising, labor, and delivery) must be covered for the operation to be truly profitable [12].

\section{Conclusion}

The artisanal fish smoking enterprise which is the most used method of preserving fish in Nigeria do not only have advantage of prolonging shelf life of fish but also improves flavor and is most preferred of the masses [14] apart from being a good source of income for business minded persons as the result of this study has revealed. Although this result suggests that fish be bought preferably from wholesalers and sold mostly in urban market for the most profit to be made, yet, its quiet revealing that extra stress needed to sell in urban market is not encountered in rural markets from which sales are faster and early turnover are met. Moreover, most people (made up of the poor masses or middle class) prefer purchasing from the rural markets where you find commodities in their abundance and at a very affordable price.

\section{Appendix 1}

\section{Cost and profit estimate calculations}

To get the value of $\mathrm{C}_{\mathrm{sw}}$ for fish sold at either rural or urban markets, values of fish, firewood and extra additives are halved since the total quantity purchased is divided in order rto be sold in the different markets. Thus;

$$
\begin{aligned}
& \mathrm{Cs}_{\mathrm{w}}=\mathrm{X}_{\mathrm{w}} \mathrm{K}_{\mathrm{w}}+\mathrm{X}_{\mathrm{fw}} \mathrm{K}_{\mathrm{fw}}+\mathrm{X}_{\mathrm{a}} \mathrm{K}_{\mathrm{a}}+\mathrm{dc}+\mathrm{mc} \\
&=3 \times 2000+1 \times 100+1 / 2 \times 50+9.3+7.36 \\
&=6000+100+25+9.3+7.36 \\
&= \\
& \mathrm{Cs}_{\mathrm{r}}=\mathrm{X}_{\mathrm{r}} \mathrm{K}_{\mathrm{r}}+\mathrm{X}_{\mathrm{fw}} \mathrm{K}_{\mathrm{fw}}+\mathrm{X}_{\mathrm{a}} \mathrm{K}_{\mathrm{a}}+\mathrm{dc}+\mathrm{mc} \\
&=3 \times 3000+1 \times 100+1 / 2 \times 50+9.3+7.36 \\
&=9000+100+25+9.3+7.36 \\
&=9141.66 \\
& \mathrm{Gs}_{\mathrm{wur}_{\mathrm{r}}}=\mathrm{R}_{\mathrm{wur}}-\mathrm{Cs}_{\mathrm{w}}-\mathrm{t}-\mathrm{c} \\
& \quad=12000-6141.66-340-100 \\
&=5418.34 \\
& \mathrm{Gs}_{\mathrm{wr}_{\mathrm{r}}}=\mathrm{R}_{\mathrm{wr}}-\mathrm{Cs}_{\mathrm{w}} \\
&= 9000-6141.66 \\
&= 2858.34 \\
& \mathrm{Gs}_{\mathrm{rur}}=\mathrm{R}_{\mathrm{rur}}-\mathrm{Cs}_{\mathrm{r}}-\mathrm{t}-\mathrm{c} \\
&=12000-9141.66-340-100 \\
&=2418.34 \\
& \mathrm{Gs}_{\mathrm{rr}}=\mathrm{R}_{\mathrm{rr}}-\mathrm{Cs}_{\mathrm{r}} \\
&=9600-9141.66 \\
&=458.34
\end{aligned}
$$

\section{References}

[1] Agbabiaka L. A. (2010a): Aquaculture and Pond management in the tropics. Vintage books limited, Owerri. 111p.

[2] FAO. (2007). The State of World Fisheries and Aquaculture 2006. Rome. 162 pp.

[3] Adekoya, B. B. and Miller, J. W. (2004)."Fish Cage Culture Potential in Nigeria". An Overview. National Agriculture Focus. An Agricultural News Magazine Published by Foundation Consultants Limited, Abuja. 1 (5): Pp 10. 
[4] Nations Newspaper, Nigeria 12/6/15 pg. 50.

[5] Okonta, A. A. and J. K. Ekelemu, (2005). A preliminary study of micro-organisms associated with fish spoilage in Asaba, Southern Nigeria. Proceedings of the 20th Annual Conference of the Fisheries Society of Nigeria, November 14-18, 2005, Port Harcourt, pp 557-560.

[6] Nyarko, H. D., Obodai, E. A., Boamponsem, L. K., Coomson, S. S., \& Aniwe, Y. (2011). Microbial profile of smoked sardine (Sardinellaaurita) at smoking sites and market centres of Tema, Ghana-1. Archives of Applied Science Research, 3 (3), 443-453.

[7] Adeyemi, O. T., Osilesi, O. O., Onajobi, F., Adebawo, O., \& Afolayan, A. J. (2013). Stability study of smoked fish, horse mackerel (Trachurus trachurus) by different methods and storage at room temperature. African Journal of Biochemistry Research, 7 (6), 98-106.

[8] George F. O. A., Ogbolu A. O., Olaoye O. J., Obasa S. O., Idowu A. A. and Odulate D. O., (2014). Fish Processing Technologies in Nigeria: A Case Study of Ibeju-Lekki Local Government Area, Lagos State. American Journal of Food Technology, 9: 302-310.

[9] Kirema-Mukasa C. T. and Reynolds J. E. (1991), Marketing and consumption of fish in Uganda, in FAO, Fisheries and Aquaculture Department, Project Reports: Uganda. p. 82.

[10] FAO, (1996). Fisheries and aquaculture in Sub-Saharan Africa: Situation and outlook in 1996. FAO Fisheries Circular No. 922, FAO, Rome, Italy, pp: 1-44.

[11] Suleiman, Aminu B. (2007). Economic analysis of artisanal fish marketing in Kebbi State of Nigeria. Thesis Submitted To School Of Postgraduate Studies, Ahmadu Bello University Zaria. (Unpublished).
[12] Andrew M. Lazur (1997). Small Scale, On-farm Fish Processing. A publication of Southern regional aquaculture center. Nunber 442.

[13] Abolagba, O. J. and Nuntah, J. N. (2011). Survey on cured fish processing, packaging, distribution and marketing in Edo and Delta states. International Research Journal of Biotechnology. 2 (5): 103-113.

[14] World Bank. (2010). The hidden harvests: the global contribution of capture fisheries. Washington DC, World Bank. 99 pp.

[15] Sérot, T., Baron, R., Knockaert, C. \&Vallet, J. L. (2004). Effect of smoking processes on the contents of 10major phenolic compounds in smoked fillets of herring (Cuplea harengus). Food Chem., 85, 111-120.

[16] Fábio H. V. Hazin, D. Sc. (2013). Fisheries And Their Contribution To Sustainable Development: Sustainable Development: Small-Scale And Artisanal Fisheries. The Sixth Meeting of the United Nations Open- ended Informal Consultative Process on Oceans Oceans and the Law of the Sea.

[17] Joseph K. (2001). Nicaragua Country Profile. Fishery College, University of Tromsø.

[18] Economic engineering applied to the fishery industr: profitability of artisanal fisheries. Fishery and Aquaculture Economics and Policy Division ISBN: 9253037385, ISSN: 0429-9345. 